\title{
Patterns in planktonic metabolism in the Mediterranean Sea
}

\author{
A. Regaudie-de-Gioux, R. Vaquer-Sunyer, and C. M. Duarte \\ Department of Global Change Research, IMEDEA (CSIC-UIB) Instituto Mediterráneo de Estudios Avanzados, \\ Miquel Marqués 21, 07190 Esporles, Spain
}

Received: 19 August 2009 - Published in Biogeosciences Discuss.: 31 August 2009

Revised: 19 November 2009 - Accepted: 8 December 2009 - Published: 17 December 2009

\begin{abstract}
Planktonic gross community production (GPP), net community production (NCP) and community respiration (CR) across the Mediterranean Sea was examined in two cruises, THRESHOLDS 2006 and 2007, each crossing the Mediterranean from West to East to test for consistent variation along this longitudinal gradient in late spring to early summer. GPP averaged $2.4 \pm 0.4 \mathrm{mmol} \mathrm{O}_{2} \mathrm{~m}^{-3} \mathrm{~d}^{-1}$, CR averaged $3.8 \pm 0.5 \mathrm{mmol} \mathrm{O}_{2} \mathrm{~m}^{-3} \mathrm{~d}^{-1}$, and NCP averaged $-0.8 \pm 0.6 \mathrm{mmol} \mathrm{O}_{2} \mathrm{~m}^{-3} \mathrm{~d}^{-1}$ across the studied sections, indicative of a tendency for a net heterotrophic metabolism in late spring to early summer, prevalent across studied sections of the Mediterranean Sea as reflected in $70 \%$ of negative NCP estimates. The median $P / R$ ratio was 0.6 , also indicating a strong prevalence of heterotrophic communities $(P / R<1)$ along the studied sections of the Mediterranean Sea. The communities tended to be net heterotrophic (i.e. $P / R<1)$ at GPP less than $2.8 \mathrm{mmol} \mathrm{O}_{2} \mathrm{~m}^{-3} \mathrm{~d}^{-1}$. The Western Mediterranean tended to support a higher gross primary production and community respiration than the Eastern basin did, but these differences were not statistically significant (ttest, $p>0.05$ ). The net heterotrophy of the studied sections of the Mediterranean Sea indicates that allochthonous carbon should be important to subsidise planktonic metabolism during the late spring.
\end{abstract}

\section{Introduction}

The Mediterranean Sea represents an anomaly in the world ocean because it ranks amongst the most oligotrophic areas of the world while receiving significant land-derived inputs of both natural and anthropogenic materials. The Mediterranean Sea receives nutrient inputs through atmospheric de-

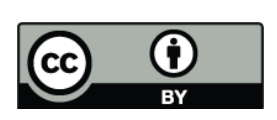

Correspondence to:

A. Regaudie-de-Gioux

(aurore.regaudie@uib.es) position across the entire basin, from riverine inputs (Martin et al., 1989; Bethoux and Gentili, 1999; Guerzoni et al., 1999), and from inputs with Atlantic water entering the Western basin. Hence, nutrient inputs are highest in the Western basin, which receives the largest riverine discharge (e.g. Rhône, France) compared to the eastern basin. Accordingly, the Mediterranean Sea has been reported to show a decreasing gradient in primary production from West to East, with primary production three times lower in the Eastern basin compared to the North-western basin (Turley, 1999). While nutrient inputs stimulate primary production, most of these inputs are accompanied by organic inputs as well, which may also stimulate planktonic respiration. Hence, it is unclear whether the reported gradient in primary production may lead to a similar west-east gradient in net community production. Yet, whether a West-East gradient in net community production exists in the Mediterranean Sea has not yet been resolved, due to a paucity of reports on planktonic metabolism in the Mediterranean Sea, particularly on the Eastern basin, as the bulk of the data available derive from the Western basin, with a dominance of studies in coastal waters (Gulf of Lions, González et al., 2008; Lefèvre et al., 1997; Bay of Blanes, Duarte et al., 2004; Lucea et al., 2005; Alboran Sea, Van Wambeke et al., 2004; Majorca Island, González et al., 2008; Gazeau et al., 2005; Navarro et al., 2004). Moreover, the magnitude of gross primary production and community respiration and the possible correlation between these processes in the Mediterranean Sea remains poorly resolved. Yet, the metabolic balance of planktonic communities is a key determinant of their role in biogeochemical cycle and, particularly, the role of planktonic communities as $\mathrm{CO}_{2}$ sinks or sources affecting the atmospheresea $\mathrm{CO}_{2}$ transfer (Duarte and Prairie, 2005).

Here we evaluate gross community production (GPP) and community respiration (CR) across the Mediterranean Sea in late spring and test the hypothesis that planktonic metabolism varies consistently along the West to East gradient in the

Published by Copernicus Publications on behalf of the European Geosciences Union. 
Mediterranean Sea. We do so on the basis of two cruises across the Mediterranean Sea, THRESHOLDS 2006 and 2007, each crossing the Mediterranean from West to East and back. The first cruise covered a section from Majorca Island (Spain), Western Mediterranean, to the Black Sea, returning to Majorca Island, in June 2006, and the second cruise covered a section from Majorca Island to Alexandria (Egypt), returning to Majorca Island, in May 2007 (Fig. 1).

\section{Materials and methods}

The study was conducted on board of the Spanish R/V Garcia del Cid, involving two cruises: THRESHOLDS-2006 (4 June 2006-4 July 2006) and THRESHOLDS-2007 (6 May 2007-1 June 2007) occupying 36 and 23 stations, respectively. At each station, vertical profiles for temperature, salinity and fluorescence were taken with a Seabird CTD attached to a Rosette sampling system. The metabolism of the planktonic communities was measured in the THRESHOLDS-2006 and THRESHOLDS-2007 at 7 and 14 stations, respectively (Fig. 1).

Community metabolism (gross primary production, community respiration and net community production) was determined from changes in oxygen over $24 \mathrm{~h}$ in water samples containing communities sampled from the surface layer $(5 \mathrm{~m})$, the Deep Chlorophyll Maximum (DCM, typically between 40 and $120 \mathrm{~m})$, and at an intermediate depth $(20 \mathrm{~m}$ or $50 \mathrm{~m}$ ) at each station. Water samples collected from these depths using 10-L Niskin bottles attached to a Rosette sampler system were carefully siphoned into narrow-mouth Winkler bottles. The water samples were taken during the early morning and were protected by a dark screen to avoid exposure to solar irradiance before the onset of the incubation. The penetration of irradiance at depth was measured with a Satlantic ${ }^{\mathrm{TM}}$ OCP-100FF submarine irradiance profiler from surface to $100 \mathrm{~m}$. The percent of the surface irradiance reaching to the different sampling depths was calculated and used to adjust the incubation irradiance for the "clear" bottles to that in situ using neutral density screens. Seven replicates were used to determine the initial oxygen concentration, and seven replicates bottles were incubated for $24 \mathrm{~h}$ in the "dark" and in the "light". The Winkler bottles were incubated on deck at the water temperature corresponding to $5 \mathrm{~m}$ depth. The mean temperature difference observed between the surface layer and the DCM at the stations occupied was $3.8 \pm 0.4^{\circ} \mathrm{C}$ and the maximum difference was around $7.6^{\circ} \mathrm{C}$. This difference may enhance somewhat metabolic rates of DCM samples when incubated at surface temperature. We calculated with the activation energy equation (Raven and Geider, 1988; López-Urrutia et al., 2006), $Q_{10}$ values for $R$ of 1.60 and NCP of 1.51, suggesting that the metabolic rates presented here for the DCM layer may be $10 \%$ to $20 \%$ higher, on average, than those at the in situ temperature for the Western and the Eastern basin, respectively. This is within the

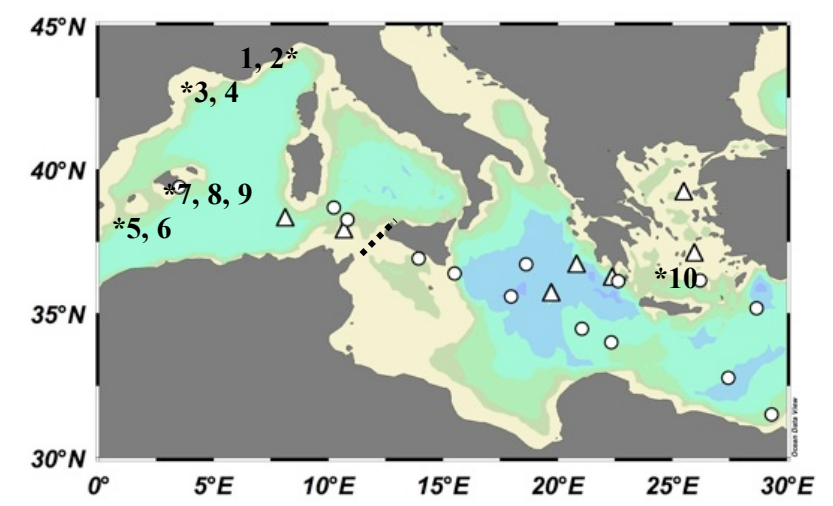

Fig. 1. Distribution of the stations occupied for planktonic metabolism determinations during the THRESHOLDS-2006 (triangles) and THRESHOLDS-2007 (circles) cruises. The dotted line delimits the western and the eastern basin across the Sicily-Tunisia Strait (SIS). Also shown the location of previous studies of community metabolism, marked with asterisks $(*)$ with the reference number of the studies shown in Table 3.

error of the estimates and, therefore, no correction was considered necessary.

Net community production (NCP) and community respiration were measured by monitoring oxygen concentration changes in the light and dark bottles along the incubation (Carpenter, 1965; Carritt and Carpenter, 1966). Oxygen concentrations were analysed by Winkler titration using a potentiometric electrode and automated endpoint detection (Mettler Toledo, DL28 titrator) (Oudot et al., 1988). CR and NCP were calculated from changes in dissolved oxygen concentration after incubation of samples under "dark" and "light" conditions, respectively and GPP was calculated by solving the mass balance equation $\mathrm{GPP}=\mathrm{NCP}-\mathrm{CR}$. The integrated metabolism rates were calculated by the trapezoid method, from the surface layer to the DCM. Occasionally, metabolism experiments failed, yielding "negative" planktonic community respiration rates (i.e. oxygen in dark bottles higher than initial values at the end of the incubation). These estimates were not considered in the analysis. Therefore, the number of stations where GPP, NCP and CR rates have been presented here, are not exactly the same.

Samples of $200 \mathrm{ml}$ for chlorophyll a determinations were filtered through Millipore GF/F filters (pressure $<0.3 \mathrm{~kg} \mathrm{~cm}^{-2}$ ), frozen and then extracted for $24 \mathrm{~h}$ with $90 \%$ acetone fluorometric determination (Turner Designs fluorometer) following Parsons et al. (1984).

Total bacterial abundance (BA) samples were determined by epifluorescence microscopy (Porter and Feig, 1980). Water subsamples of 4 and $10 \mathrm{ml}$ were filtered through $0.2 \mu \mathrm{m}$ polycarbonate black filters and stained with DAPI (4, 6-diamino-2 phenylindole) to a final concentration of $1 \mu \mathrm{g} \mathrm{ml}^{-1}$. During the cruises, BA was determined by flow cytometry by FACSCalibur Flow Cytometer (Beckton Dickinson(C) as described in Ortega-Retuerta et al. (2008). 
Samples for dissolved organic carbon (DOC) concentration analyses were taken in duplicate by transferring a volume of $10 \mathrm{ml}$ of sample into pre-combusted glass ampoules, which were then acidified with phosphoric acid to $\mathrm{pH} 2$, heat sealed and preserved in the dark until analysis. At the laboratory, samples were analysed by High Catalytic Oxidation (HTOC) technique on a Shimadzu TOC 5000 analyser (for THRESHOLDS-2006 samples) and on a Shimadzu TOC 5050 analyser (for THRESHOLDS-2007 samples) (Benner and Strom, 1993). Standards provided by Dennis A. Hansell and Wenhao Chen (University of Miami, USA) of $2 \mu \mathrm{m}$ and $45 \mu \mathrm{m}$ TOC were used to assess the accuracy of the estimates.

Samples for nutrient (nitrate + nitrite, silicate and phosphate) analyses were collected at each depth and kept frozen until analyzed in a Bran Luebe AA3 autoanalyzer using standard methods (Hansen and Koroleff, 1999).

Volumetric metabolic rate estimates (GPP, CR and NCP) for the two different cruises were tested for normality and homogeneity of variances. GPP and NCP estimates were normally distributed $(p>0.05)$, in contrast with CR estimates, which deviated from normal distribution. Variances were homogeneous for GPP, CR and NCP estimates (Levene's test, $p<0.05$ ). The Student t-test was used to compare variables distributed normally and the Kruskal-Wallis test was used to compare variables departing from normal distribution.

\section{Results}

Seawater temperature was relatively uniform across the Mediterranean, varying from $20^{\circ} \mathrm{C}$ to $23^{\circ} \mathrm{C}$ at $5 \mathrm{~m}$ depth, and from $10^{\circ} \mathrm{C}$ to $15^{\circ} \mathrm{C}$ at $100 \mathrm{~m}$ depth across the transects (data not shown). Chlorophyll a concentration was low, below $1.0 \mu \mathrm{g} \mathrm{L}^{-1}$ over the entire water column (5 to $200 \mathrm{~m}$ ) across the studied section, except in the Balearic Sea, where chlorophyll a concentration increased up to $4.5 \mu \mathrm{g} \mathrm{L}^{-1}$ at $50 \mathrm{~m}$ depth during THRESHOLDS-2006 and up to $1.2 \mu \mathrm{g} \mathrm{L}^{-1}$ at $70 \mathrm{~m}$ depth in the Sicily-Tunisia Strait, during THRESHOLDS-2007 (Fig. 2). Total BA showed similar average values during THRESHOLDS-2006 $\left(5.9 \pm 1.1 \times 10^{5}\right.$ cell ml $\left.^{-1}\right)$ and THRESHOLDS $2007\left(5.0 \pm 0.3 \times 10^{5} \mathrm{cell} \mathrm{m}^{-1}\right.$, Table 1$)$. BA showed higher values in the Eastern basin during THRESHOLDS $2006\left(7.6 \pm 1.2 \times 10^{5} \mathrm{cell} \mathrm{ml}^{-1}\right)$ than during THRESHOLDS $2007\left(4.7 \pm 0.4 \times 10^{5} \mathrm{cell}^{-1}\right)$ and the opposite was observed in the Western basin, with BA higher during THRESHOLDS $2007\left(6.2 \pm 0.4 \times 10^{5} \mathrm{cell} \mathrm{ml}^{-1}\right)$ than during Thresholds $2006\left(2.4 \pm 1.3 \times 10^{5}\right.$ cell ml $\left.^{-1}\right)$.

Nutrient concentrations were generally low (Table 1), particularly for phosphate, which was often below the detection limit $\left(0.05 \mu \mathrm{mol} \mathrm{PL} \mathrm{L}^{-1}\right)$ of the analysis. Dissolved organic carbon ranged two fold within basins (Table 1), with DOC concentrations generally declining with depth. During THRESHOLDS 2006, seawater surface had an average DOC concentration of $120 \mu \mathrm{molCL} \mathrm{CL}^{-1}$ and decreased to reach
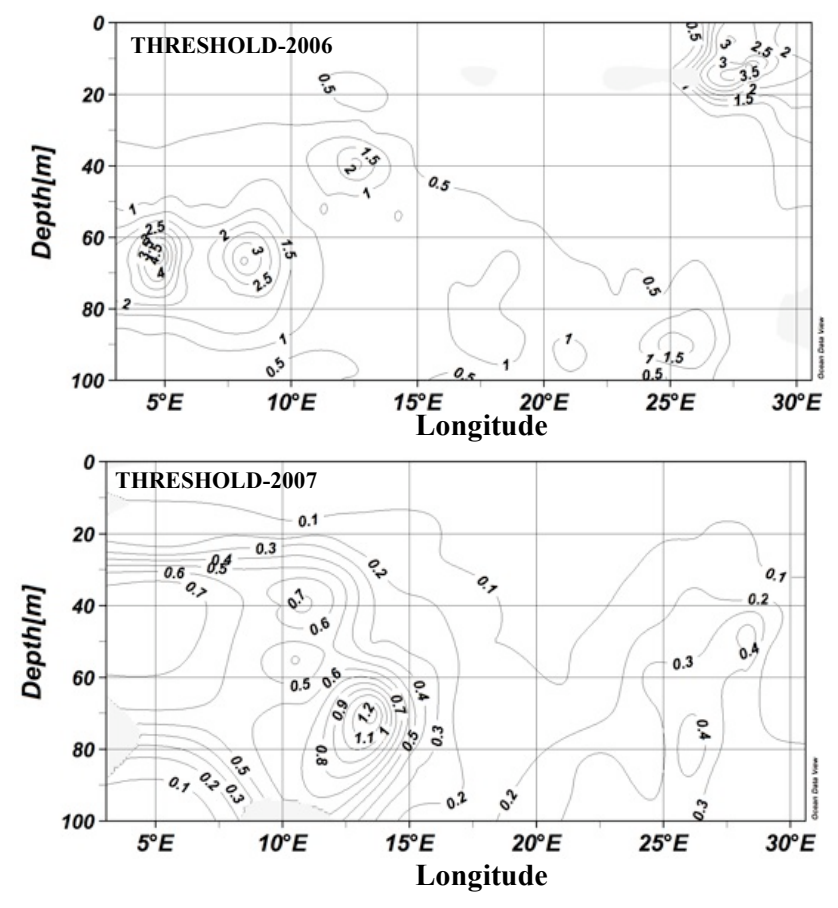

Fig. 2. Chlorophyll $a\left(\mathrm{mg} \mathrm{m}^{-3}\right)$ profiles across the Mediterranean Sea during the THRESHOLDS-2006 and THRESHOLDS-2007 cruises.

$50 \mu \mathrm{mol} \mathrm{CL} \mathrm{L}^{-1}$ at $100 \mathrm{~m}$ depth. A DOC concentration increase to $100 \mu \mathrm{molCL} \mathrm{L}^{-1}$ was observed at in Sicily Strait. During THRESHOLDS 2007, DOC concentrations showed an average of $100 \mu \mathrm{mol} \mathrm{CL^{-1 }}$ above $50 \mathrm{~m}$ depth, and decreased with depth to a mean value of $75 \mu \mathrm{mol} \mathrm{C} \mathrm{L}{ }^{-1}$ at $100 \mathrm{~m}$ depth.

GPP averaged $\left( \pm\right.$ SE) $\quad 2.4 \pm 0.4 \mathrm{mmol} \mathrm{O}_{2} \mathrm{~m}^{-3} \mathrm{~d}^{-1}$ across the sections (Table 1) and remained below $10 \mathrm{mmolO}_{2} \mathrm{~m}^{-3} \mathrm{~d}^{-1}$ in the euphotic zone (Fig. 3), except for the subsurface maxima of the Aegean Sea (at $25.92^{\circ} \mathrm{E}$ ) where GPP reached $15.1 \mathrm{mmol} \mathrm{O}_{2} \mathrm{~m}^{-3} \mathrm{~d}^{-1}$. GPP differed significantly between the THRESHOLDS 2006 and 2007 (t-test, $p=0.012$ ) with higher rates observed in the THRESHOLDS 2006 cruise. GPP showed a diversity of vertical profiles, from lack of vertical structure to strong vertical heterogeneity with surface or deep maxima (Fig. 3). $\mathrm{CR}$ averaged $3.8 \pm 0.5 \mathrm{mmol} \mathrm{O}_{2} \mathrm{~m}^{-3} \mathrm{~d}^{-1}$ and also remained, for the majority of stations, below $10 \mathrm{mmol} \mathrm{O}_{2} \mathrm{~m}^{-3} \mathrm{~d}^{-1}$ throughout the sections (Table 1). CR was significantly higher in THRESHOLDS 2006 than in THRESHOLDS 2007 (Kruskal-Wallis test, $p=0.031$ ). CR also showed a diversity of vertical profile patterns across the stations, typically including a subsurface maximum (Fig. 3).

$\mathrm{NCP}$ averaged $-0.8 \pm 0.6 \mathrm{mmol} \mathrm{O}_{2} \mathrm{~m}^{-3} \mathrm{~d}^{-1}$ across the sections (Table 1) and showed contrasting vertical patterns (Fig. 3). NCP was similar between the THRESHOLDS 2006 and 2007 cruises and did not differ across the basins. NCP values were below $5 \mathrm{mmolO}_{2} \mathrm{~m}^{-3} \mathrm{~d}^{-1}$, with a prevalence 
Table 1. Mean, SE, Range and number of estimates of volumetric gross primary production (GPP), community respiration (CR) and net community production (NCP) rates $\left(\mathrm{mmol} \mathrm{O}_{2} \mathrm{~m}^{-3} \mathrm{~d}^{-1}\right)$, DOC (Dissolved Organic Carbon, $\mu \mathrm{mol} \mathrm{C} \mathrm{L}{ }^{-1}$ ), nutrients concentrations $\left(\mu \mathrm{mol} \mathrm{L}{ }^{-1}\right)$ and bacterial abundance $\left(10^{5} \mathrm{cell} \mathrm{ml}^{-1}\right)$ in the western and eastern Mediterranean basins, during THRESHOLDS 2006 (1) and 2007 (2).

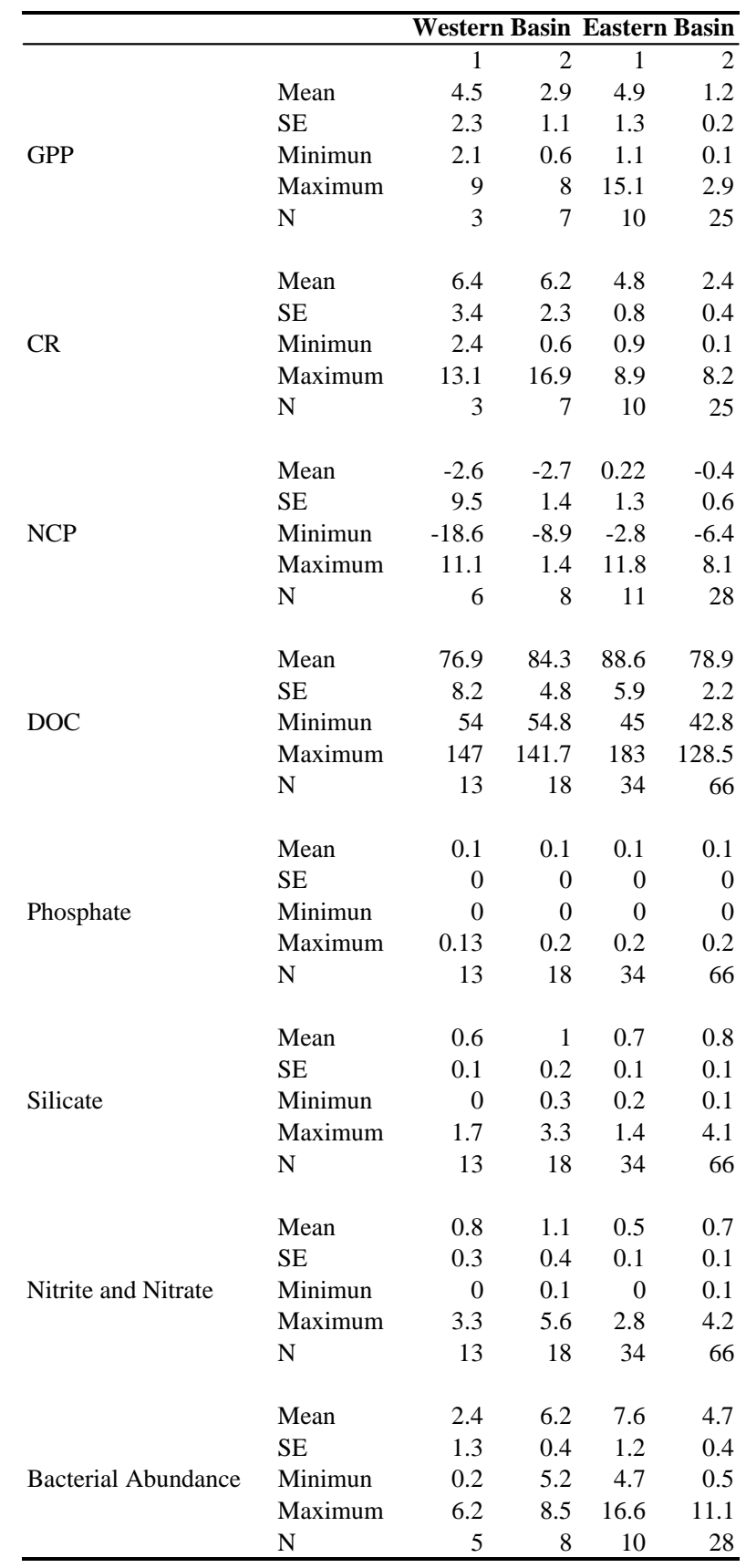

Biogeosciences, 6, 3081-3089, 2009
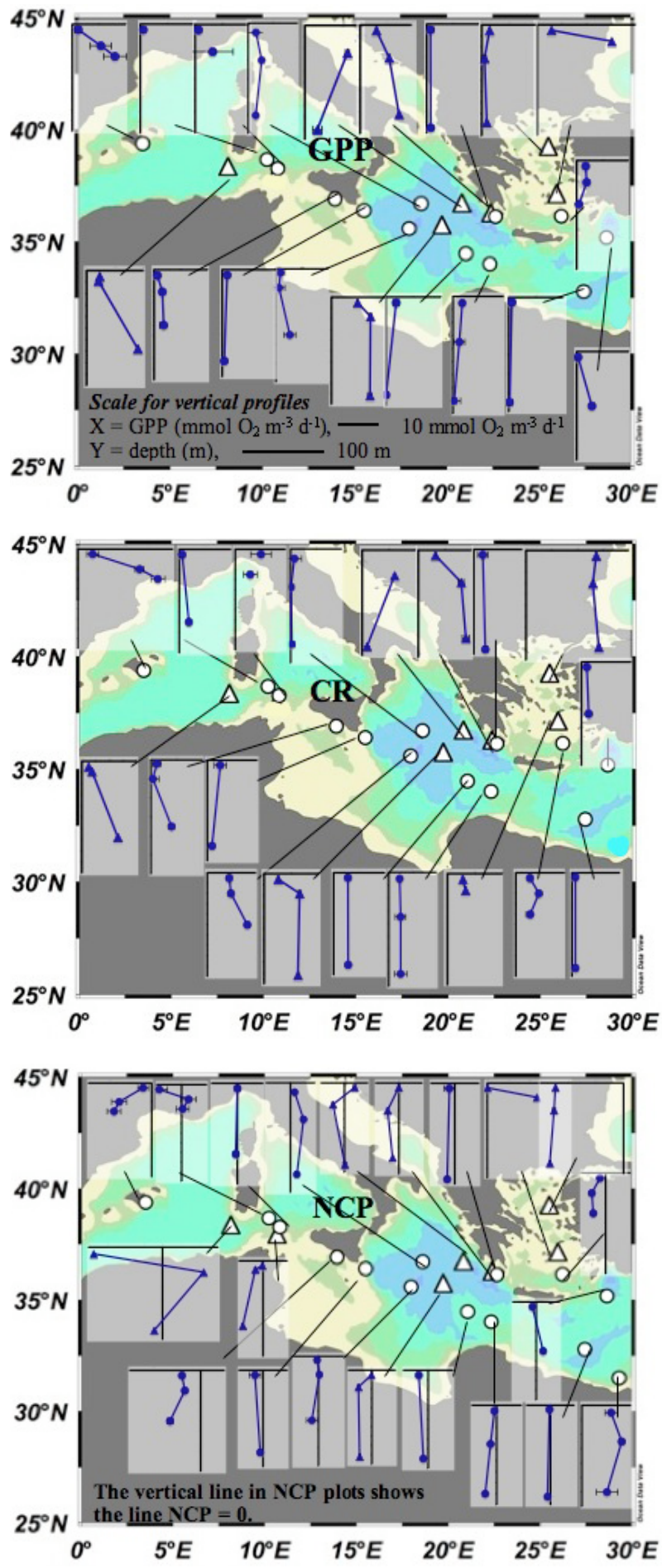

Fig. 3. Vertical profiles of gross primary production (GPP, $\mathrm{mmol} \mathrm{O}_{2} \mathrm{~m}^{-3} \mathrm{~d}^{-1}$ ), community respiration (CR, $\mathrm{mmol} \mathrm{O}_{2} \mathrm{~m}^{-3} \mathrm{~d}^{-1}$ ) and net community production (NCP) $\left(\mathrm{mmolO}_{2} \mathrm{~m}^{-3} \mathrm{~d}^{-1}\right)$ profiles at each station along the Mediterranean studies combined for the THRESHOLD-2006 (triangles) and 2007 (circles) cruises (for more detailed information see supplementary material: http://www.biogeosciences.net/6/3081/ 2009/bg-6-3081-2009-supplement.pdf). 
of negative values (70\% of the estimates) indicative of a prevalence of net heterotrophic communities during the two cruises. The median $P / R$ ratio was 0.6 indicating also a strong prevalence of heterotrophic communities $(P / R<1)$ along the studied sections during late spring. The majority of the Mediterranean regions examined supported heterotrophic communities, except for the Ionian Sea with a $P / R$ ratio of 1.35 (Table 3 ), where autotrophic communities prevailed. No significant relationships were observed between the metabolic rates (GPP, CR and NCP) and nutrient concentrations, DOC concentrations or bacterial abundance $(p>0.05)$.

The $P / R$ ratio tended to increase significantly $\left(r^{2}=0.34\right.$, $p<0.05$ ) with increasing gross primary production (Fig. 4 ) implying that the studied communities tended to be net heterotrophic (i.e. $P / R<1$ ) at low GPP and net autotrophic at high GPP. The volumetric GPP required for production to balance respiration (GPP at $\mathrm{GPP}=R$ ) was $2.8 \mathrm{mmol} \mathrm{O}_{2} \mathrm{~m}^{-3} \mathrm{~d}^{-1}$, with the GPP threshold for the Western basin being more than 2-fold higher $\left(\mathrm{GPP}=4.7 \mathrm{mmol} \mathrm{O}_{2} \mathrm{~m}^{-3} \mathrm{~d}^{-1}\right)$ than that for the Eastern basin $\left(\mathrm{GPP}=1.9 \mathrm{mmol} \mathrm{O}_{2} \mathrm{~m}^{-3} \mathrm{~d}^{-1}\right)$.

\section{Discussion}

The two cruises presented here showed a broad range of planktonic metabolic rates across the Mediterranean. The volumetric GPP and CR, as well as the chlorophyll a concentration, were significantly higher during THRESHOLDS-2006 than THRESHOLDS-2007 (Kruskal-Wallis test, $p<0.001$ ). Whereas GPP and NCP tended to be somewhat higher in the western compared to the eastern basin, these differences were not statistical significant, so no significant West-East gradient in planktonic metabolism was supported by our data.

Planktonic communities across the studied sections during late spring tended to be heterotrophic, consistent with available reports of metabolic seasonality for the NW Mediterranean littoral (Duarte et al., 2004; Navarro et al., 2004; Satta et al., 1996). The prevalence of heterotrophic conditions during the studied period was consistent with the supersaturation in $\mathrm{CO}_{2}$ of surface Mediterranean waters across the THRESHOLDS 2006 cruise (more than 20 stations), with the mean $p \mathrm{CO}_{2}$ in surface waters exceeding atmospheric equilibrium by, on average, $40 \pm 14 \mathrm{ppm}$ (Vaquer-Sunyer, unpublished data). These data are in accordance with the data observed by D'Ortenzio et al. (2008) and Copin-Montégut et al. (2004) who showed surface Mediterranean seawaters to be supersaturated in $p \mathrm{CO}_{2}$ during late spring-early summer. In contrast, the mean atmospheric $p \mathrm{CO}_{2}$ during THRESHOLDS 2007 was $371 \mu$ atm (mean sea-air difference $-18 \pm 4$ ppm, Álvarez, unpublished data), implying that the Mediterranean Sea acted as a sink for atmospheric $\mathrm{CO}_{2}$, possibly a legacy from the late winter-early spring bloom preceding this cruise. Some pub-

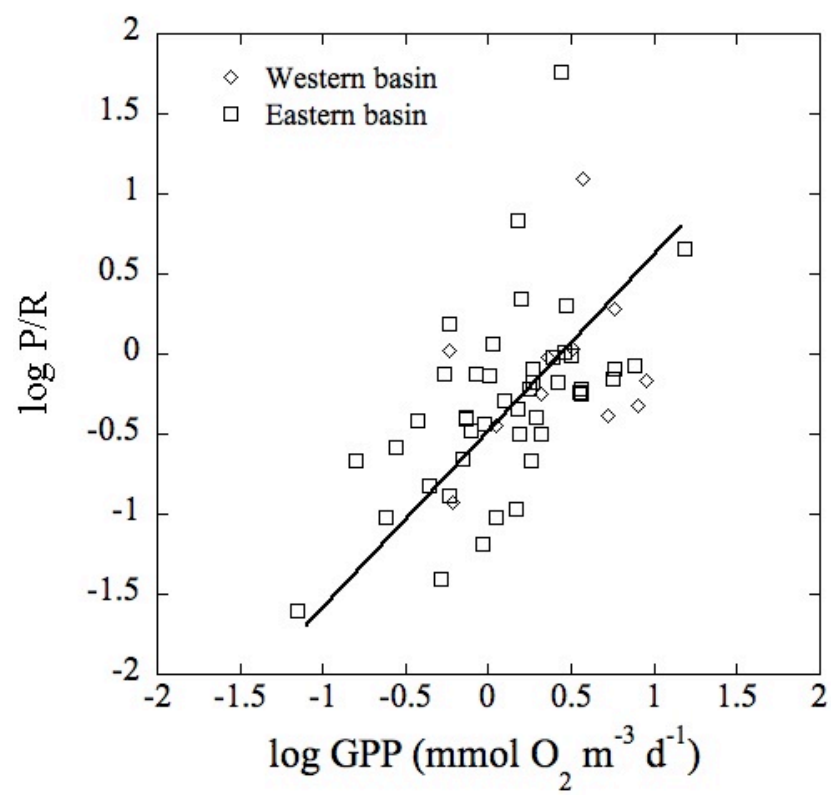

Fig. 4. The relationship between log of gross primary production to community respiration ratio $(P / R)$ and log of gross primary production ( $\left.\mathrm{mmol} \mathrm{O}_{2} \mathrm{~m}^{-3} \mathrm{~d}^{-1}\right)$ in the Western (diamonds) and Eastern (squares) basins of the Mediterranean Sea. The solid line shows the fitted linear regression model II equation (both basins): $\log$ $P / R=1.09( \pm 0.12) \log$ GPP $-0.48( \pm 0.06)\left(r^{2}=0.34, p<0.0001\right)$.

lished works reported the presence of late winter (FebruaryMarch) phytoplankton blooms (Duarte et al., 2004; Navarro et al., 2004; Agusti and Duarte, 2000; Lefèvre et al., 1997). Lefèvre et al. (1997) explained that in winter the Rhône River water moves rapidly westwards, providing fresh nutrients into the Gulf of Lion, and giving rise to a winter diatom bloom. Navarro et al. (2004) observed high values of GPP in February, coinciding with the late winter phytoplankton bloom when high chlorophyll a concentration was observed. Gazeau et al. (2005) observed also a phytoplankton bloom in March at Palma de Mallorca Bay. These observations, describing a late winter-early spring phytoplankton bloom, may account for the relatively low $\mathrm{CO}_{2}$ values observed during THRESHOLDS 2007.

The $P / R$ ratio tended to increase with increasing GPP (Fig. 4) indicating that the most productive areas, associated with the Sicily-Tunisia Strait separating the West and East basins, tend to support net autotrophic planktonic communities. Comparison of GPP rates between autotrophic $(\mathrm{NCP}>0)$ and heterotrophic $(\mathrm{NCP}<0)$ samples showed that the mean GPP tended to be higher, but not significantly so (t-test, $p>0.05$ ), for autotrophic (GPP mean $=3.5 \pm 1.1 \mathrm{mmol} \mathrm{O}_{2} \mathrm{~m}^{-3} \mathrm{~d}^{-1}$ ) than for heterotrophic (GPP mean $=2.2 \pm 0.3 \mathrm{mmol} \mathrm{O}_{2} \mathrm{~m}^{-3} \mathrm{~d}^{-1}$ ) communities. However, there were significant differences (ttest, $p<0.05$ ) in GPP between autotrophic and heterotrophic communities once the major differences in GPP among 
Table 2. Western to Eastern ratios of planktonic community components and processes integrated to the DCM (Deep Chlorophyll Maximum). Ratios for this study were calculated as the ration of the mean value for each basin.

\begin{tabular}{lcl}
\hline Variable & West:East & References \\
\hline $\begin{array}{l}\text { Bacteria biomass } \\
\left(\mathrm{mg} \mathrm{C} \mathrm{m}^{-2}\right)\end{array}$ & 0.75 & Turley et al. (2000) \\
$\begin{array}{l}\text { Bacterial production } \\
\left(\mathrm{mg} \mathrm{C} \mathrm{m}^{-2} \mathrm{~d}^{-1}\right)\end{array}$ & 1.87 & Turley et al. (2000) \\
$\begin{array}{l}\text { Bacterial growth rate } \\
\left(\mathrm{d}^{-1}\right)\end{array}$ & 2.27 & Turley et al. (2000) \\
$\begin{array}{l}\text { Net Primary Production } \\
\left.(\mathrm{mg} \mathrm{C} \mathrm{m})^{-2} \mathrm{~d}^{-1}\right)\end{array}$ & 3.33 & Turley et al. (2000) \\
$\begin{array}{l}\text { Chlorophyll } \\
\left.(\mathrm{mg} \mathrm{m})^{-2}\right)\end{array}$ & 1.13 & Turley et al. (2000) \\
$\begin{array}{l}\text { Chlorophyll } a \\
\left.(\mathrm{mg} \mathrm{m})^{-2}\right)\end{array}$ & 1.55 & This study \\
$\begin{array}{l}\text { GPP } \\
\left(\mathrm{mmol} \mathrm{O}_{2} \mathrm{~m}^{-2} \mathrm{~d}^{-1}\right)\end{array}$ & 1.37 & This study \\
$\begin{array}{l}\mathrm{CR} \\
\left(\mathrm{mmol} \mathrm{O}_{2} \mathrm{~m}^{-2} \mathrm{~d}^{-1}\right)\end{array}$ & 1.74 & This study \\
$\begin{array}{l}\mathrm{NCP} \\
\left(\mathrm{mmol} \mathrm{O} \mathrm{m}^{-2} \mathrm{~d}^{-1}\right)\end{array}$ & $1.46^{*}$ & This study \\
\hline
\end{tabular}

* Mean net community production was negative, heterotrophic, so that the ratio $>1$ implies NCP to be more negative in the Western than in the Eastern basin.

cruises were considered. Hence, planktonic communities tended to be net heterotrophic at low GPP and net autotrophic at high GPP within any one cruise.

Turley (2000) reported significant gradients between the western and the eastern basin in primary production (West to East ratio $=3.33, p=0.018$, t-test), bacterial production (West to East ratio=1.87, $p=0.029$ ) and bacterial growth rate (West to East ratio $=2.27, p=0.007$ ). Our data suggest a similar, but not significant $(p>0.05)$, trend across basins for GPP (West to East ratio $=1.37$, t-test, $p=0.68$ ) and for CR (West to East ratio $=1.74$, t-test, $p=0.37$ ), consistent with the enhanced bacterial abundance and activity in the Western basin reported by Turley (2000). Hence, NCP in the Western basin tended to be more negative than that in the Eastern Basin (Table 2). However, the important variability within basins rendered these differences in metabolic rates not statistically significant ( $p=0.88$, t-test). Although GPP seems to be enhanced in the less oligotrophic Western basin relative to the Eastern basin, CR is increased as well as riverine inputs are accompanied by important loads of organic matter (Lefèvre et al., 1997; Moutin et al., 1998; de Madron et al., 2002) that enhance community respiration. Accordingly, planktonic communities in the Western Mediterranean also tended to be heterotrophic in this study during late spring.
This study reports the first assessment of planktonic community metabolism across the Mediterranean during late spring of two yearly consecutives cruises, as previous reports focussed on particular regions, mostly coastal areas in the NW Mediterranean (Table 3, Fig. 5). In addition to riverine inputs, atmospheric inputs, which are high across the Mediterranean (Guerzoni et al., 1999), are an important source of organic carbon (Dachs et al., 2005; Jurado et al., 2008), providing, along with riverine inputs, the allochtonous carbon required to support net heterotrophic communities.

The metabolic rates observed in the THRESHOLDS cruises were somewhat higher than previously reported rates (Table 3). This could be explained by the fact that most previous studies were conducted during the winter and/or fall, whereas planktonic metabolic rates are highest, both for CR and GPP, in early summer, when an increase in metabolic rate per unit autotrophic and heterotrophic biomass has been reported for the Mediterranean Sea (Satta et al., 1996; Duarte et al., 2004). Also some of the literature rates were derived from shallow littoral stations (Table 3), where vertically integrated metabolic rates were constrained by the water column depth available.

Our study shows that net heterotrophic communities prevailed at GPP rates $<4 \mathrm{mmol} \mathrm{O}_{2} \mathrm{~m}^{-3} \mathrm{~d}^{-1}$ during late spring for the studied sections of the Mediterranean Sea. The GPP threshold for metabolic balance for this study is somewhat higher than those reported earlier for NW Mediterranean coastal areas (Bay of Palma: $2.8 \mathrm{mmol} \mathrm{O}_{2} \mathrm{~m}^{-3} \mathrm{~d}^{-1}$, Navarro et al., 2004; and Bay of Blanes: $3.8 \mathrm{mmol} \mathrm{O}_{2} \mathrm{~m}^{-3} \mathrm{~d}^{-1}$, Duarte et al., 2004) and well above that for the global ocean $\left(1.1 \mathrm{mmol} \mathrm{O}_{2} \mathrm{~m}^{-3} \mathrm{~d}^{-1}\right.$, Duarte and Regaudie-deGioux, 2009), implying that the GPP necessary to balance community respiration for Mediterranean communities during these studies is three times higher than that for the global ocean. This suggests that a higher gross primary production is required to compensate for the excess respiration supported by the high inputs of allochthonous organic carbon to the Mediterranean Sea during late spring.

In conclusion, the study presented here provides evidence that the planktonic communities of the studied regions during the late spring in the Mediterranean Sea tend to be net heterotrophic, as supported by previous reports from studies conducted mostly in coastal areas. Whereas the Western Mediterranean supports a higher gross primary production than the eastern basin does, it also supports higher community respiration rates, so that net community production tends to be more negative in the Western than in the Eastern basin during late spring. Planktonic metabolism in the Mediterranean Sea is likely to be very sensitive to changes in organic carbon inputs. Regulation of major rivers (Rhône, Ebro, Nile, Po) discharging in the Mediterranean, changes in the aerosol load over the Mediterranean, and increased human population in the basin may all have affected community metabolism and the role of planktonic communities in the $\mathrm{CO}_{2}$ budget of the Mediterranean Sea. Whereas the data 
Table 3. Geometric mean of the integrated (euphotic zone) planktonic metabolic rates $\left(\mathrm{mmol} \mathrm{O}_{2} \mathrm{~m}^{-2} \mathrm{~d}^{-1}\right)$ and of the $P / R$ ratio for different studies of planktonic communities metabolism in the Mediterranean Sea (Fig. 1). The number of stations (N station) and number of individual volumetric estimates ( $\mathrm{N}$ depth) in each study is also shown. We just took into account stations with metabolism analysed for 3 depths.

\begin{tabular}{|c|c|c|c|c|c|c|c|c|c|}
\hline Authors & Region & Date & $\begin{array}{c}\text { Depth } \\
\text { (m) }\end{array}$ & GPP & $\mathbf{R}$ & NCP & $\mathbf{P} / \mathbf{R}$ & $\begin{array}{c}\mathbf{N} \\
\text { station } \\
\end{array}$ & $\begin{array}{c}\mathrm{N} \\
\text { depth }\end{array}$ \\
\hline 1 Lefèvre et al. (1997) & Gulf of Lions & 12/1988 - 03/1992 & 53 & 72,2 & 72,7 & $-0,5$ & 1 & 19 & 83 \\
\hline 2 González et al. (2008) & Gulf of Lions & $\begin{array}{l}\text { 10/2002; 12/2002; } \\
03 / 2003 ; 06 / 2003\end{array}$ & 30 & 24,7 & 26,5 & 1,5 & 0,7 & 4 & 16 \\
\hline 3 Duarte et al. (2004) & Bay of Blanes & 03/1988 - 10/1994 & 5 & 12.9 & 23.4 & -10.5 & 0,6 & 333 & 333 \\
\hline 4 Lucea et al. (2005) & Bay of Blanes & 01/1996 - 12/1997 & 15 & 28.3 & 41.3 & -13.0 & 0.7 & 23 & 23 \\
\hline 5 Lefèvre et al. (PANGEA 2001) & Alboran Sea & 12/1997 - 01/1998 & 60 & 34.8 & 40.3 & -5.5 & 0,9 & 8 & 40 \\
\hline 6 VanWambeke et al. (2004) & Alboran Sea & $12 / 2001-01 / 2002$ & 80 & 25.9 & 33.0 & -7.1 & 0,8 & 7 & n.d. \\
\hline 7 Navarro et al. (2004) & Bay of Palma & 06/2001 - 10/2002 & 7 & 23.2 & 27.9 & -4.7 & 0,8 & 14 & 14 \\
\hline 8 Gazeau et al. (2005) & Bay of Palma & 03/2002 - 06/2002 & 26 & 68.0 & 54.0 & 15 & 1,3 & 4 & 32 \\
\hline 9 González et al. (2008) & Bay of Palma & 06/2002 & 20 & 46 & 58,1 & $-6,4$ & 1,1 & 4 & 16 \\
\hline 10 Robinson (2000) & Aegean Sea & $\begin{array}{l}\text { 06/1996; 09/1996; } \\
\text { 06/1997 }\end{array}$ & 7 & 25.2 & 130.2 & -105.0 & 0,2 & 10 & 16 \\
\hline This study & Western basin & 06/2006; 05/2007 & 54 & 195,9 & 370,3 & $-155,4$ & 0,6 & 3 & 9 \\
\hline This study & Eastern basin & 06/2006; 05/2007 & 63 & 118,6 & 156,9 & $-82,9$ & 1,3 & 9 & 27 \\
\hline
\end{tabular}

a data reported in carbon units converted to oxygen units assuming a 1.25 molar stoichiometry between $\mathrm{O}_{2}$ and C (Williams, 1979; Davies and Williams, 1984).

n.d.=not determined.

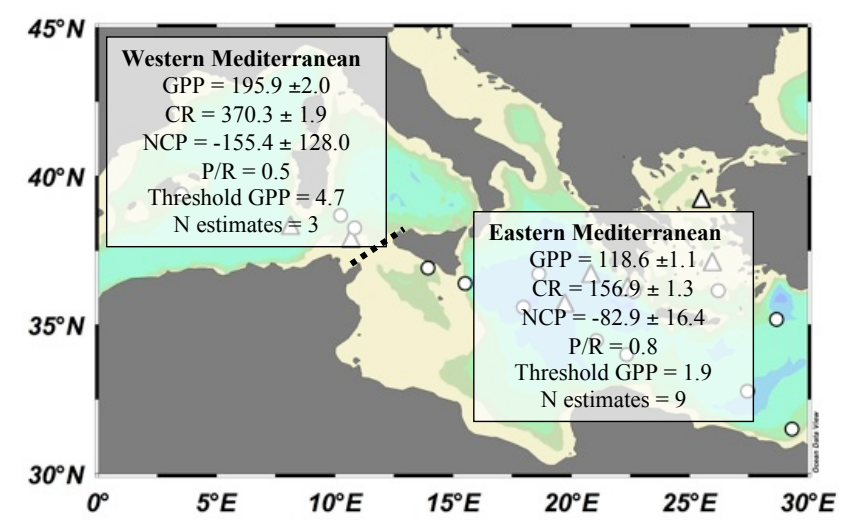

Fig. 5. Integrated (0-100 m) geometric mean $( \pm$ SE) metabolic rates $\left(\mathrm{mmol} \mathrm{O} \mathrm{m}^{-2} \mathrm{~d}^{-1}\right)$ in the western and eastern basins $(N=22)$, along with the corresponding geometric integrated mean $P / R$ ratio, threshold GPP for GPP $=R$, and number of estimates $(N)$ for this study. The Geometric means were calculated for stations with metabolism analysed at 3 depths.

presented here represent the first evaluations of planktonic metabolism across the Mediterranean basin, our results are restricted to the late spring-early summer period and cannot resolve the annual metabolic balance of the communities. Indeed, resolving simultaneously the variability in planktonic metabolism across seasons and at the basin scale is a daunting task, which has not been completed as yet at the basin scale for any sea. The data presented here, although limited in their own right, provide a useful and unique resource to continue to improve and validate models, such as that presented by D'Ortenzio et al. (2008), that can be used, once properly validated, to integrate across scales. The combination of large-scale surveys, such as those presented here, and models may help resolve the metabolic balance of Mediterranean planktonic communities and its response to organic inputs delivered by river discharge and aerosol inputs.

Acknowledgements. This research was funded by the THRESHOLDS integrated project (003933-2), funded by the Framework Program 6 of the EU, and a complementary action (CTM200524238-E) funded by the Plan Nacional de I+D, Spanish Ministry of Science and Innovation. A. Regaudie-de-Gioux was supported by the EU Marie Curie EST project Metaoceans (MEST-CT-2005019678). We thank M. Álvarez for $p \mathrm{CO}_{2}$ data for THRESHOLDS 2007, R. Santiago and P. Echeveste for chlorophyll a analyses, S. Lasternas and E. Ortega-Retuerta for bacterial abundance 
analyses, J. C. Alonso, R. Santiago and R. Martínez for nutrient and DOC analyses and the captains and crew of the R/V García del Cid and the technicians of the UTM on board for their help and cooperation.

Edited by: J. Middelburg

\section{References}

Benner, R. and Strom, M.: A critical evaluation of the analytical blank associated with the DOC measurements by hightemperature catalytic oxidation, Mar. Chem., 41, 153-160, 1993.

Bethoux, J. P. and Gentili, B.: Functioning of the Mediterranean Sea: past and present changes related to freshwater input and climate changes, J. Mar. Syst., 20(1-4), 33-47, 1999.

Carpenter, J. H.: The accuracy of the Winkler method for dissolved oxygen analysis, Limnol. Oceanogr., 10, 135-140, 1965.

Carrit, D. E. and Carpenter, J. H.: Comparison and evaluation of currently employed modifications of the Winkler method for determining dissolved oxygen in sea-water, J. Mar. Res., 24, 286318, 1966.

Claustre, H., Marty, J.-C., and Cassiani, L.: Intraspecific differences in the biochemical composition of a diatom during a spring bloom in Villefrance-sur-mer Bay, Mediterranean Sea, J. Exp. Mar. Biol. Ecol., 129, 17-32, 1989.

Copin-Montégut, C., Bégovic, M., and Merlivat, L.: Variability of the partial pressure of $\mathrm{CO}_{2}$ on diel to annual time scales in the Northwestern Mediterranean Sea, Mar. Chem., 85, 169-189, 2004.

Cruzado, A., Velàsquez, Z., Pérez, M. del C., Bahamòn, N., Grimaldo, N. S., and Ridolfi, F.: Nutrient fluxes from the Ebro river and subsequent across-shelf dispersion, Cont. Shelf Res., 22, 349-360, 2002.

Dachs, J., Calleja, M. L., Duarte, C. M., del Vento, S., Turpin, B., Polidori, A., Herndl, G., and Agusti, S.: High atmosphere-ocean exchange of organic carbon in the NE Subtropical Atlantic, Geophys. Res. Lett., 32, L21807, doi:10.1029/2005GL023799, 2005.

Davies, J. M. and Williams, P. J. le B.: Verification of ${ }^{14} \mathrm{C}$ and $\mathrm{O}_{2}$ derived primary organic production measurements using an enclosed ecosystem, J. Plankt. Res., 6(3), 457-474, 1984.

de Madron, X. D., Denis, L., Diaz, F., Garcia, N., Guieu, C., Grenz, C., Loÿe-Pilot, M.-D., Ludwig, W., Moutin, T., Raimbault, P., and Ridame, C.: Nutrients and carbon budgets for the Gulf of Lion during the Moogli cruises, Oceanol. Acta, 26(4), 421-433, 2003.

D’Ortenzio, F., Antoine, D., and Marullo, S.: Satellite-driven modeling of the upper ocean mixed layer and air-sea $\mathrm{CO}_{2}$ flux in the Mediterranean Sea, Deep-Sea Res. (1. Oceanogr. Res. Pap.), 55, 405-434, 2008.

Duarte, C. M. and Agusti, S.: The $\mathrm{CO}_{2}$ balance of unproductive aquatic ecosystems, Science, 281, 234-236, 1998.

Duarte, C. M., Agusti, S., and Vaqué, D.: Controls on planktonic metabolism in the Bay of Blanes, northwestern Mediterranean littoral, Limnol. Oceanogr., 49(6), 2162-2170, 2004.

Duarte, C. M. and Prairie, Y. M.: Prevalence of heterotrophy and atmospheric $\mathrm{CO}_{2}$ emissions from aquatic ecosystems, Ecosystems, 8, 862-870, 2005.

Duarte, C. M. and Regaudie-de-Gioux, A.: Thresholds of Gross Primary Production for the Metabolic Balance of Marine Planktonic
Communities, Limnol. Oceanogr., 54, 1015-1022, 2009.

Gazeau, F., Duarte, C. M., Gattuso, J.-P., Barrón, C., Navarro, N., Ruiz, S., Prairie, Y. T., Calleja, M., Delille, B., Frankignoulle, M., and Borges, A. V.: Whole-system metabolism and $\mathrm{CO}_{2}$ fluxes in a Mediterranean Bay dominated by seagrass beds (Palma Bay, NW Mediterranean), Biogeosciences, 2, 43-60, 2005 , http://www.biogeosciences.net/2/43/2005/.

González, N., Gattuso, J.-P., and Middelburg, J. J.: Oxygen production and carbon fixation in oligotrophic coastal bays and the relationship with gross and net primary production, Aquat. Microb. Ecol., 52, 119-130, 2008.

Guerzoni, S., Chester, R., Dulac, F., Herut, B., Loÿe-Pilot, M.-D., Measures, C., Migon, C., Molinaroli, E., Moulin, C., Rossini, P., Saydam, C., Soudine, A., and Ziveri, P.: The role of atmospheric deposition in the biogeochemistry of the Mediterranean Sea, Prog. Oceanogr., 44, 147-190, 1999.

Hansen, K. and Koroleff, F. F.: Determination of nutrients, in: Methods of seawater analysis, edited by: Grasshoff, K., Kremling, K., and Ehrhardt, M., Wiley-VCH, Germany, 159-228, 1999.

Jurado, E., Dachs, J., Duarte, C. M., and Simò, R.: Atmospheric deposition of organic and black carbon to the global ocean, Atmos. Environ., 42(34), 7931-7939, 2008.

Lefèvre, D., Minas, H. J., Minas, M., Robinson, C., LeB Williams, P. J., and Woodward, E. M. S.: Review of gross community production, primary production, net community production and dark community respiration in the Gulf of Lions, Deep-Sea Res. (1. Oceanogr. Res. Pap.), 44(3-4), 801-832, 1997.

López-Urrutia, Á., San Martin, E., Harris, R. P., and Irigoyen, X.: Scaling the metabolic balance of the oceans, P. Natl. Acad. Sci.,103(23), 8739-8744, 2006.

Lucea, A., Duarte, C. M., Agusti, S., and Kennedy, H.: Nutrient dynamics and ecosystem metabolism in the Bay of Blanes (NW Mediterranean), Biogeochemistry, 73, 303-323, 2005.

Martin, J.-M., Elbaz-Poulichet, F., Guieu, C., Loye-Pilot, M.-D., and Hans, G.: River versus atmospheric input of material to the Mediterranean Sea: An overview, Mar. Chem., 28(1-3), 159182, 1989.

Morel, A. and André, J.-M.: Pigment distribution and primary production in the western Mediterranean as derived and modeled from Coastal Zone Color Scanner observations, J. Geophys. Res., 96, 12685-12698, 1991.

Moutin, T., Raimbault, P., Golterman, H. L., and Coste, B.: The input of nutrients by the Rhône river into the Mediterranean Sea: recent observations and comparison with earlier data, Hydrobiologia, 373/374, 237-246, 1998.

Navarro, N., Agustì, S., and Duarte, C. M.: Plankton metabolism and dissolved organic carbon use in the Bay of Palma, NW Mediterranean Sea, Aquat. Microb. Ecol., 37, 47-54, 2004.

Ortega-Retuerta, E., Reche, I., Pulido-Villena, E., Agusti, S., and Duarte, C. M.: Explorring the relationship between active bacterioplankton and phytoplankton in the Southern Ocean, Aquat. Microb. Ecol., 52, 99-106, 2008.

Oudot, C., Gerard, R., Morin, P., and Gningue, I.: Precise Shipboard Determination of Dissolved-Oxygen (Winkler Procedure) for Productivity Studies with a Commercial System, Limnol. Oceanogr., 33(1), 146-150, 1988.

Parsons, T. R., Maita, Y., and Lalli, C. M.: A manual of chemical 
and biological methods for seawater analysis, Pergamon Press, Oxford, 173 pp., 1984.

Porter, K. G. and Feig, Y. S.: The use of DAPI for identifying and counting aquatic microflora, Limnol. Oceanogr., 25, 943-948, 1980.

Raven, J. A. and Geider, R. J.: Temperature and algal growth, New Phytol., 110, 441-461, 1988.

Robinson, C.: Plankton gross production and respiration in the shallow water hydrothermal systems of Miles, Aegean Sea, J. Plankton Res., 22(5), 887-906, 2000.

Satta, M. P., Agusti, S., Mura, M. P., Vaqué, D., and Duarte, C. M.: Microplankton respiration and net community metabolism in a bay on the NW Mediterranean coast, Aquat. Microb. Ecol., 10, 165-172, 1996.

Spyres, G., Nimmo, M., Worsfold, P. J., and Achterberg, E. P.: Determination of dissolved organic carbon in seawater using high temperature catalytic oxidation techniques, Trends in Anal. Chem., 19(8), 498-506, 2000.
Turley, C. M.: The changing Mediterranean Sea - a sensitive ecosystem?, Prog. Oceanogr., 44, 387-400, 1999.

Turley, C. M., Bianchi, M., Christaki, U., Conan, P., Harris, J. R. W., Psarra, S., Ruddy, G., Stutt, E. D., Tselepides, A., and Van Wambeke, F.: Relationship between primary producers and bacteria in an oligotrophic sea - the Mediterranean and biogeochemical implications, Mar. Ecol. Prog. Ser., 193, 11-18, 2000.

Van Wambeke, F., Lefèvre, D., Prieur, L., Sempéré, R., Bianchi, M., Oubelkheir, K., and Bruyant, F.: Distribution of microbial biomass, production, respiration dissolved organic carbon and factors controlling bacterial production across a geostrophic front (Almeria-Oran, SW Mediterranean Sea), Mar. Ecol. Prog. Ser., 269, 1-15, 2004.

Williams, P. J. le B., Raine, R. C. T., and Bryan, J. R.: Agreement between the ${ }^{14} \mathrm{C}$ and oxygen methods of measuring phytoplankton production: reassessment of the photosynthetic quotient, Oceanol. Acta, 2, 441-416, 1979. 